\title{
SISTEM KAMERA CERDAS UNTUK DETEKSI PELANGGARAN MARKA JALAN
}

\author{
Anang Mashudi ${ }^{1}$, Faqih Rofii ${ }^{2}$, Mohammad Mukhsim ${ }^{3}$ \\ 1,2,3, Teknik Elektro Universitas Widyagama Malang \\ Email : anangmasuwg@gmail.com
}

\begin{abstract}
Abstrak
Penghitungan jumlah kendaraan dan deteksi pelanggaran rambu-rambu lalu lintas sejauh ini masih dilakukan sacara manual. Berkembangnya teknik pengolahan citra yang berasal dari sensor kamera mendorong adanya implementasi sistem pemantauan pelanggaran kendaraan pada area lampu lalu lintas dengan menggunakan kamera cerdas. Tujuan penelitian adalah mengembangkan sistem yang dapat mendeteksi dan menghitung jumlah kendaraan berupa mobil yang melanggar garis marka jalan. Metode pengolahan citra yang dikembagkan pada penelitian ini adalah mengubah citra video RGB hasil tangkapan kamera menjadi grayscale kemudian menerapkan teknik harr cascade untuk mendeteksi adanya pelanggaran garis marka jalan. Sistem yang dikembangkan mampu menghitung jumlah kendaraan yang melewati sensor kamera pada lajur jalan yang dipantau dan mendeteksi adanya pelanggaran pada marka jalan dengan akurasi deteksi sebesar $76 \%$ dibandingkan dengan pengamatan secara langsung oleh mata manusia.
\end{abstract}

Kata kunci: Kamera cerdas, marka jalan, lalu lintas, haar cascade, pemantauan

\begin{abstract}
The calculation of the number of vehicles and the detection of violations of traffic signs so far do manually. The development of image processing techniques originating from camera sensors has led to the implementation of a vehicle violation monitoring system in the traffic light area using smart cameras. The purpose of this research is to develop a system that can detect and count the number of vehicles in the form of cars that violate the road markings. The image processing method developed in this study is to change the RGB video image of the camera catches to grayscale and then apply the Harr cascade technique to detect any road markings violations. The developed system can count the number of vehicles that pass camera sensors on the monitored lane and detect violations on road markings with a detection accuracy of 76\% compared to direct observation by the human eye.
\end{abstract}

Keywords: Smart cameras, road markings, traffic, haar cascades, monitoring

JASEE Journal of Application and Science on Electrical Engineering 


\section{PENDAHUluan}

Berbagai macam pelanggaran yang terjadi di jalan raya sering kali membuat banyak pengguna jalan menjadi resah. Penyebab terjadinya pelanggaran tersebut adalah ketidaktahuan pengemudi kendaraan akan aturan yang berlaku, kelalaian pengemudi kendaraan dan perilaku penggun jalan [1]. Basis data kepolisian Indonesia mencata bahwa terjadi peningkatan jumlah kejadian kecelakaan dari Desember 2016 sampai Serptember 2017 terutama yang diakibatkan karena melanggar garis marka zebra cross dan menerobos lampu merah. Semakin banyak pelanggaran yang terjadi, maka dapat meningkatkan kemungkinan kecelakaan yang dapat menimbulkan korban dann kerugian material. Karena kecelakaan lalu lintas sebagian besar diakibatkan oleh pengendara yang melanggar aturan lalu lintas [2]. Tentunya diharapkan ada suatu cara atau metode untuk memantau pelanggaran lalu lintas secara cerdas sebagai upaya untuk mengurangi pelanggaran lalu lintas sehingga mengurani terjadinya kecelakaan.

Teknologi pemantauan dengan menggunakan kamera cerdas berbasis pengolahan citra video sekarang ini terus berkembang. Penelitian yang telah dilakukan oleh Ali Mahdi, dkk menguji akurasi deteksi jumlah kendaraan roda empat yang melintas dengan metode luasan piksel [3]. Dalam penelitian tersebut disimpulkan perhitungan kendaraan roda empat dengan tingkat akurasi hingga $82.18 \%$ pada waktu siang hari dan tingkat akurasi hingga $88.3 \%$ pada waktu malam hari. Selanjutnya pada penelitian Bagus, dkk telah dilakukan penelitian serupa namun dengan metode berbeda yakni frame intersection [4]. Dalam penelitian tersebut disimpulkan bahwa sistem yang direalisasikan sudah mampu menghilangkan objek-objek selain kendaraan khususnya garis jalan meskipun pada beberapa frame masih terdapat sedikit garis jalan. Berikutnya pada penelitian Rama Adistya, dkk telah dilakukan penelitian serupa dengan metode yang berbeda, yakni menggunakan backpropagation neural network dan sobel [5].

Dalam penelitian tersebut disimpulkan bahwa penggunaan metode backpropagation dalam pengenalan golongan kendaraan menghasilkan akurasi yang tinggi pada pengenalan bentuk mobil dengan persentase 94\%. Namun dalam penelitian pertama hanya difokuskan pada perhitungan jumlah kendaraan roda empat, sedangkan pada penelitian kedua tingkat akurasi penghitungan kendaraan masih kurang, sehingga tidak akurat dalam mendeteksi jumlah kendaraan. Pada penelitian ketiga penggunaan metode yang diterapkan belum dapat mengenali jenis kendaraan secara spesifik yang disebabkan oleh ada beberapa jenis mobil yang memiliki variabel yang sama.

Berdasar pada kekurangan tersebut, penelitian ini bertujuan untuk merancang suatu sistem pemantauan cerdas menggunakan kamera webcam untuk memantau secara kontinyu dan waktu nyata. Kinerja dari sistem pengawasan ini didasarkan pada kemampuan deteksi kendaraan roda empat yang melintas di jalan raya. Jika kendaraan tersebut melanggar garis marka jalan, maka sistem akan menghitung kendaraan tersebut dan dinyatakan melanggar garis marka. Untuk dapat mendeteksi jumlah kendaraan dan meningkatkan akurasi deteksi kendaraan, digunakan operasi pengambangan (thresholding) untuk memisahkan obyek dari gambar latar belakangnya dalam suatu citra yang dicuplik dari video rekaman. Dengan dirancangnya sistem tersebut, akan memudahkan dalam proses pengawasan pelanggaran yang dapat dilakukan secara terus-menerus. 


\section{STUDI PUSTAKA}

Berkembangnya teknologi di bidang visi komputer memungkinkan untuk mendapatkan dan menginterpretasi informasi visual dari lingkungan melalui perangkat komputer, sehingga mampu mendeteksi dan mengklasifikasi berbagai jenis objek berdasarkan informasi visual yang masuk [6]. Untuk mengolah informasi visual, maka dibutuhkan pengetahuan di bidang pengolahan citra digital yaitu disiplin ilmu yang mempelajari teknik pengolahan citra digital menggunakan komputer dengan algoritma tertentu. Biasanya suatu citra akan diolah dahulu pada tingkat terendah untuk meningkatkan kualitas gambar dengan menghilangkan noise. Kemudian citra tersebut diolah pada tingkat yang lebih tinggi dengan suatu algoritma, seperti untuk deteksi pola dan bentuk dan mengetahui objek apa yang ada di dalam citra [7].

Citra adalah adalah suatu fungsi kontinyu dengan intensitas cahaya pada bidang dua dimensi secara matematis. Untuk dapat diolah oleh komputer, maka suatu citra harus dipresentasikan secara numerik dengan nilai-nilai diskrit. Repersentasi dari fungsi kontinyu menjadi nilai-nilai diskrit disebut digitalisasi citra. Suatu citra digital melalui suatu teknik pengolahan akan menghasilkan citra digital yang baru, termasuk di dalamnya adalah perbaikan citra (image restoration) dan peningkatan kualitas citra (image enhancement). Sedangkan analisis citra digital menghasilkan suatu keputusan atau suatu data, termasuk di dalamnya adalah pengenalan pola [8]. Pengolahan citra banyak diterapkan untuk berbagai bidang, antara lain untuk mendeteksi objek dengan normalisasi RGB [9], klasifikasi jenis kendaraan [10],[11].

Haar like Feature merupakan metode yang lazim digunakan dalam pendeteksian obyek. Nama Haar sendiri mengacu pada Haar Wavelet, sebuah fungsi matematika yang berbentuk kotak dan memiliki prinsip seperti pada fungsi Fourier. Haar-like features merupakan fungsi persegi, yang memberikan indikasi secara spesifik pada sebuah citra gambar. Prinsip Haar-like features adalah mengenali obyek berdasarkan nilai sederhana dari fitur tetapi bukan merupakan nilai piksel dari Image obyek tersebut. Metode ini memiliki kelebihan yaitu komputasinya sangat cepat, karena hanya bergantung pada jumlah piksel dalam persegi bukan setiap nilai piksel dari sebuah citra [7]. Haar like feature dikembangkan oleh Viola dan Jones untuk memproses gambar yang berada dalam kotak dengan kandungan beberapa pixel yang terkandung di dalamnya. Setiap kotak yang diproses akan menghasilkan perbedaan nilai yang menandakan daerah gelap dan terang, nilai tersebut yang dijadikan sebagai dasar pemrosesan citra selanjutnya.

Untuk menghitung nilai fitur dari gambar yang ada di dalam kotak yaitu dengan cara mengurangkan nilai pixel pada daerah berwarna lebih putih dengan pixel pada daerah yang lebih gelap. Integral image digunakan pada metode haar cascade untuk mempermudah penghitungan nilai fitur. Pemjumlahan nilai pixel dari kiri atas hingga kanan bawah disebut sebagi integral image. Pengolahan haar cascase menggunakan citra grayscale, yaitu citra yang telah diubah unsur warna RGB-nya menjadi warna abu-abu. Sebagai contoh pada citra grayscale 1-bit, setiap pikselnya memiliki $2^{4}=2$ varian nilai intensitas yaitu nilai $0,1,2$, dan 3 , di mana nilai 0 direpresentasikan oleh warna hitam, nilai 1 warna abu-abu gelap, nilai 2 warna abu-abu terang, dan nilai 3 warna putih.

JASEE Journal of Application and Science on Electrical Engineering 


\section{METODE}

Metode penelitian yang dilakukan pada penelitian ini melalui tahapantahapan sebagai berikut:

\subsection{Studi literatur}

Tahap ini dilakukan untuk mendapatkan informasi-informasi tentang penelitian sebelumnya dalam sistem pemantauan jalan berbasis kamera. Studi literatur dilakukan dengan mengkaji literatur sebelumnya dan menerapkan konsep sesuai dengan yang diinginkan, yakni pembuatan smart surveillance system untuk pemantauan pelanggaran marka jalan pada lampu lalu lintas.

\subsection{Perencanaan sistem}

Tahap ini dilakukan untuk merencanakan sistem kerja dalam pembuatan penelitian sesuai dengan latar belakang dan rumusan masalah. Perencanaan sistem kerja meliputi kebutuhan hardware dan software yang diperlukan selama penelitian serta keterkaitan antar keduanya. Sehingga dalam pembuatan terjadi keruntutan dan tidak ada bagian-bagian yang terlompati. Berikut blok diagram yang ditunjukkan oleh gambar 1 .

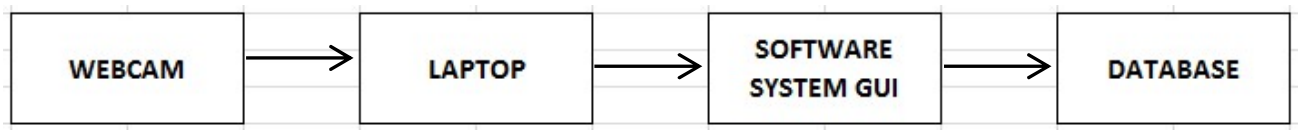

\section{Gambar 1. Diagram Blok Sistem}

Webcam berfungsi sebagai perekam video di jalan dan masukan input data video untuk dikirim ke laptop melalui kabel USB. Laptop berfungsi sebagai hardware penyimpanan program aplikasi GUI yangdijalankan oleh Python. Tampilan GUI merupakan tampilan dari aplikasi Smart Surveillance system. Dalam aplikasi ini akan ditampilkan video yg sedang terekam oleh webcam secara livedan dilakukan proses perhitungan mobil yang tengah melintas di perempatan jalan raya untuk mengetahui mobil yang melanggar marka maupun tidak. Dalam GUI ini juga terdapat tampilan waktu real saat pengambilan video oleh webcam. Database sebagai penyimpanan hasil perhitungan mobil yang melanggar marka dan tidak melanggar marka, serta waktu kejadiannya akan direkam kedalam database.

\subsection{Pembuatan program}

Tahap ini dilakukan untuk implementasi algoritma pada suatu program yang dikerjakan menggunakan software Phyton. Berikut diagram alir dari blok sistem yang ditunjukkan oleh Gambar 2. 


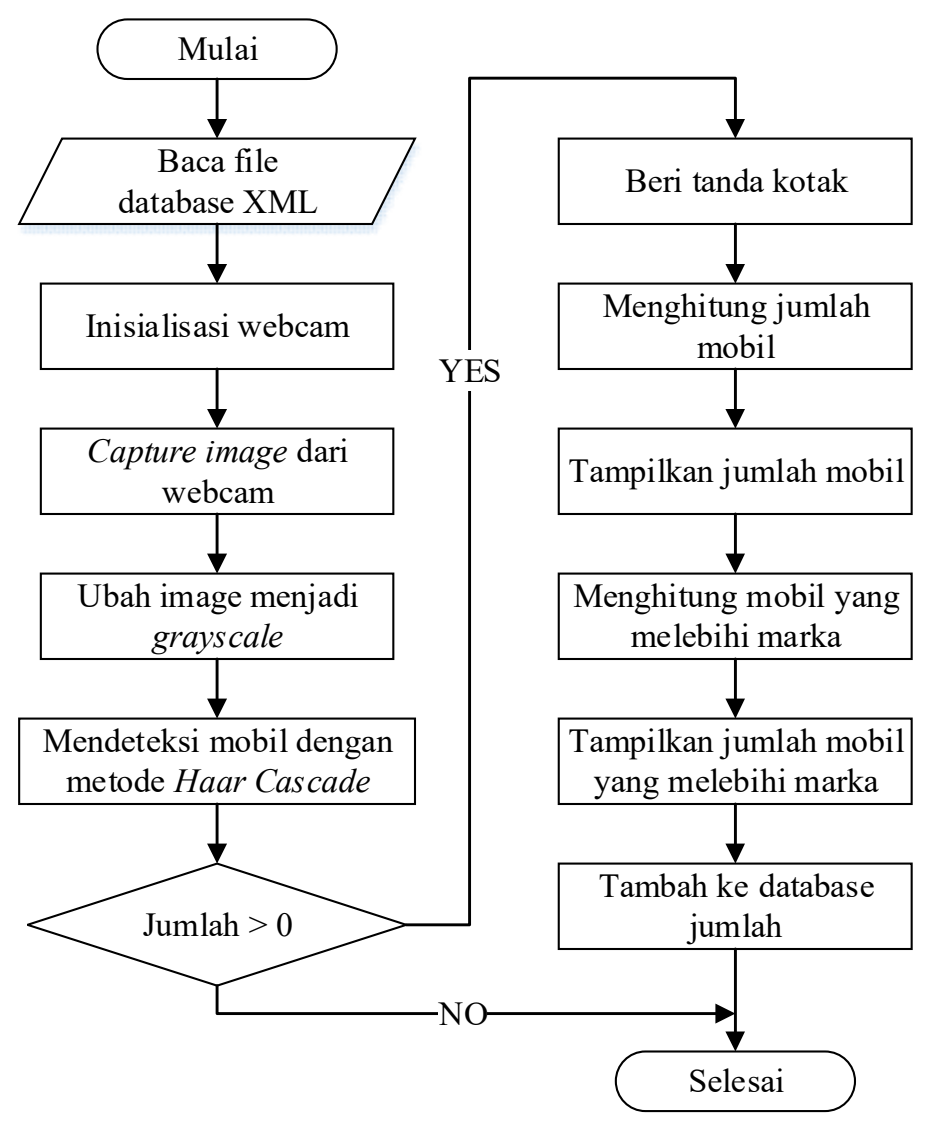

Gambar 2. Diagram Alir kerja Sistem

Diagram alir dari sistem keseluruhan adalah sebagai berikut :

a. Membaca file database XML.

b. Inisialisasi webcam dengan cara menghubungkannya dengan laptop melalui kabel USB.

c. Mengambil image dari webcam.

d. Mengubah image RGB menjadi image grayscale.

e. Mendeteksi mobil dengan menggunakan metode Haar Cascade.

f. Jika jumlah mobil yang terdeteksi melebihi 0 , maka lakukan penghitungan mobil. Jika tidak, maka sistem berakhir. Jika sistem mendeteksi jumlah mobil lebih dari 0 kembali, maka dilakukan penghitungan mobil ulang, begitu seterusnya.

g. Memberi tanda kotak pada area deteksi.

h. Menampilkan jumlah mobil yang terdeteksi.

i. Menghitung mobil yang melebihi garis marka.

j. Menampilkan jumlah mobil yang yang melebihi garis marka.

k. Menambahkan data-data tersebut ke database. 
Untuk menghitung kendaraan yang melakukan pelanggaran maka proses perhitungan sebagai berikut :

a. Tentukan daerah pelangaran dengan menggunakan garis warna merah dan biru

b. Jika kendaraan yang berhenti melewati garis merah, maka dianggap sebagai pelanggaran marka jalan

c. Jika kendaraan yang berhenti tidak melewati garis merah, maka dianggap sebagai tidak melanggar marka jalan

d. Menghitung jumlah mobil yang berhenti pada lampu merah

e. Ruas diluar garis biru, bukan merupakan objek yang diteliti

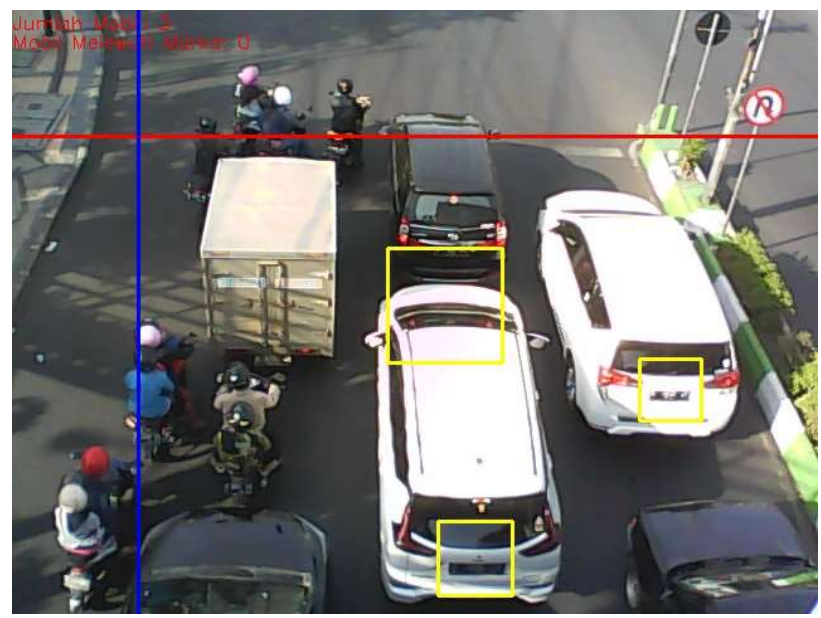

Gambar 3. Ilustrasi penghitungan mobil yang melakukan pelanggaran' 


\section{HASIL DAN PEMBAHASAN}

Penelitian ini menggunakan data situasi lalu lintas yang diambil di Jl. Ahmad Yani, Malang. Hasil pemantauan dan pembacaan data menggunakan kamera webcam longitech dan program Python pada laptop. Sistem pemantauan yang telah dirancang selanjutnya diuji pada kondisi lapangan. Adapun langkah pengujian adalah sebagai berikut :

1. Inisialisasi yaitu memberikan input nilai awal pada saat deklarasi variabel atau obyek, berupa citra gambar dengan tipe bitmap dan Jpeg.

2. Penangkapan gambar melalui webcam, proses awal yang dilakukan adalah scanning video input device. Jika video input device (webcam) ditemukan maka dilanjutkan dengan proses capture dan save image.

3. Pembacaan file data, yang akan digunakan agar dapat disinkronkan dengan webcam, sehingga ketika sampai pada tahap coding tidak akan terjadi masalah dengan pembacaan video input device (dalam hal ini webcam).

Sistem pemantauan yang dikembangkan menggunakan bahasa pemrograman python. Sistem yang dihasilkan berupa aplikasi antarmuka grafis yang menampilkan daerah pemantauan berupa garis merah dan biru. Garis merah adalah batas suatu kendaraan diidentifikasi sebagai melanggar marka jalan atau tidak. Aturannya adalah suatu kendaraan dinyatakan melanggar marka jalan, jika body dari kendaraan melewati garis merah yang ditetapkan ketika kendaraan tersebut berhenti di area lampu merah lalu lintas, dan dinyatakan tidak melanggar marka jalan, jika body dari kendaraan tidak melewati garis merah yang ditetapkan. Sedangkan garis biru adalah batas pemantauan dari sistem. Di Luar dari garis biru adalah bukan termasuk dalam area pemantauan. Tiap kendaraan mobil yang terdeteksi akan diberi tanda kotak.

Penelitian dilakukan pada siang dan sore hari, yaitu pada rentang waktu pukul $09.00-11.00$ WIB. Sedangkan pada sore dilakukan pada rentang waktu puku; 15.00 - 17.00 WIB. Ketika sistem mendeteksi adanya kendaraan mobil yang melanggar atau mendeteksi kendaraan mobil namun tidak melanggar dalam bentuk kotak, maka dinyatakan sebagai True, sedangkan ketika sistem salah mendeteksi bentuk kendaraan yang bukan mobil sebagai False. Gambar 4, 5 dan 6 mewakili sistem yang mendeteksi kendaraan yang dinyatakan sebagai kondisi True dan False.

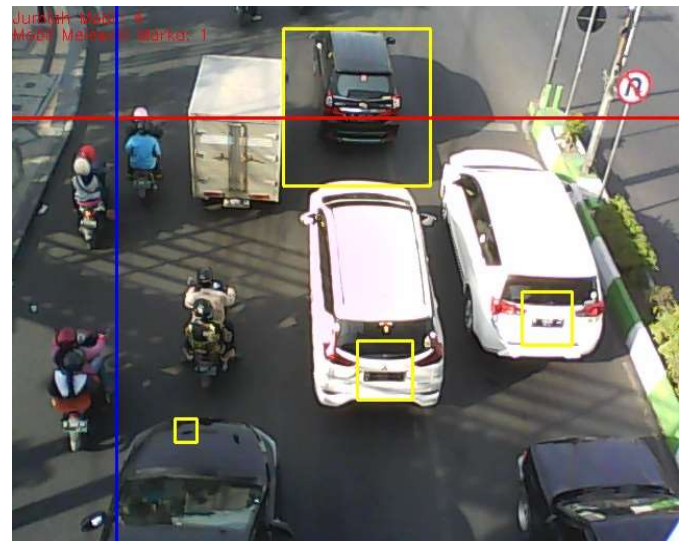

Gambar 4. Sistem mendeteksi pelanggaran marka jalan dinyatakan TRUE 


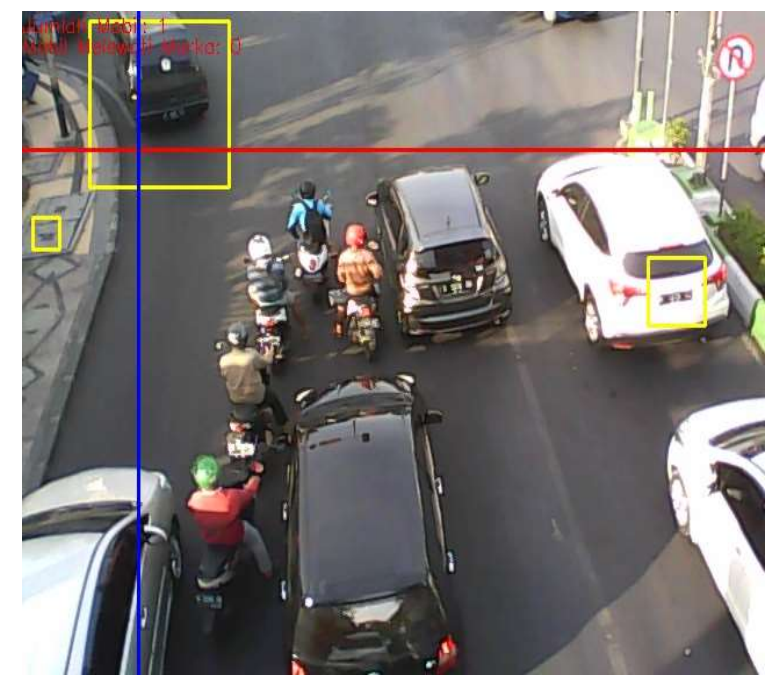

Gambar 5. Sistem mendeteksi 1 mobil tanpa pelanggar marka jalan dinyatakan TRUE

Pada Gambar 5. Sistem mendeteksi objek dengan 1 mobil tanpa pelanggar marka jalan. Garis biru menunjukkan pembatas, di mana bagian sebelah kiri adalah petunjuk jalan terus, sehingga walaupun kondisi lampu merah melewati garis marka, tidak menjadi obyek perhitungan pada sistem. Pada gambar 6, sistem melakukan kesalahan deteksi sebuah sepeda motor, namun dianggap sebagai mobil

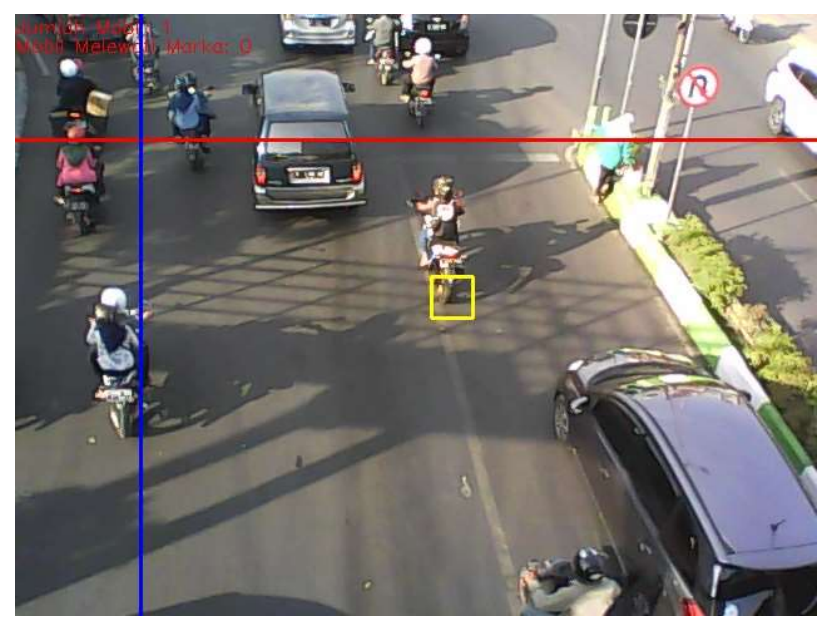

Gambar 6. Sistem mendeteksi sepeda motor sebagai mobil dinyatakan FALSE

Tabel 1 adalah 10 sample dari 367 data keseluruhan yang didapat dari pengamatan dan pengujian di lapangan. Data yang diambil merupakan hasil pengolahan sistem dari video yang diambil dan dinyatakan dalam True dan False dari beberapa kejadian. Hasil pengolahan dari sistem juga dibandingkan dengan pengamatan langsung oleh mata manusia untuk memvalidasi kebenaran dari output sistem. Sistem mendeteksi jumlah mobil yang lewat ke area pantauan dan mendeteksi ada tidaknya pelanggaran marka jalan. 
| Vol. 1 | No. 1 | Halaman 15 - 25

Tabel 1. Hasil pengujian lapangan

\begin{tabular}{|c|c|c|c|c|c|c|c|c|}
\hline \multirow[b]{2}{*}{ No } & \multirow[b]{2}{*}{ Waktu } & \multicolumn{3}{|c|}{ Sistem } & \multicolumn{3}{|c|}{ Pembanding } & \multirow[b]{2}{*}{$\begin{array}{c}\text { Gambar output } \\
\text { sistem }\end{array}$} \\
\hline & & $\begin{array}{l}\text { Jum- } \\
\text { lah }\end{array}$ & $\begin{array}{c}\text { Mele- } \\
\text { wati } \\
\text { Marka }\end{array}$ & Ket. & $\begin{array}{l}\text { Jum- } \\
\text { lah }\end{array}$ & $\begin{array}{c}\text { Mele- } \\
\text { wati } \\
\text { marka }\end{array}$ & Ket. & \\
\hline & $\begin{array}{c}\text { 18-10- } \\
06 \_15: \\
30: 17\end{array}$ & 1 & 0 & TRUE & 4 & 0 & TRUE & \\
\hline & $\begin{array}{c}18-10- \\
06 \_15: \\
30: 22\end{array}$ & 2 & 0 & TRUE & 4 & 0 & TRUE & \\
\hline & $\begin{array}{c}\text { 18-10- } \\
06 \_15: \\
30: 27\end{array}$ & 1 & 0 & TRUE & 4 & 0 & TRUE & \\
\hline & $\begin{array}{c}18-10- \\
06 \_15: \\
30: 33\end{array}$ & 2 & 0 & TRUE & 4 & 0 & TRUE & \\
\hline & $\begin{array}{c}\text { 18-10- } \\
06 \_15: \\
30: 38\end{array}$ & 2 & 0 & FALSE & 4 & 0 & TRUE & \\
\hline & $\begin{array}{c}18-10- \\
06 \_15: \\
30: 43\end{array}$ & 2 & 0 & TRUE & 4 & 0 & TRUE & \\
\hline & $\begin{array}{c}\text { 18-10- } \\
06 \_15: \\
30: 48\end{array}$ & 2 & 0 & TRUE & 4 & 0 & TRUE & \\
\hline & $\begin{array}{c}18-10- \\
06 \_15: \\
30: 53\end{array}$ & 1 & 0 & TRUE & 4 & 0 & TRUE & \\
\hline & $\begin{array}{c}\text { 18-10- } \\
06 \_15: \\
30: 59\end{array}$ & 2 & 0 & TRUE & 4 & 0 & TRUE & \\
\hline 0 & $\begin{array}{c}\text { 18-10- } \\
06 \_15: \\
31: 04\end{array}$ & 1 & 0 & TRUE & & & TRUE & \\
\hline
\end{tabular}




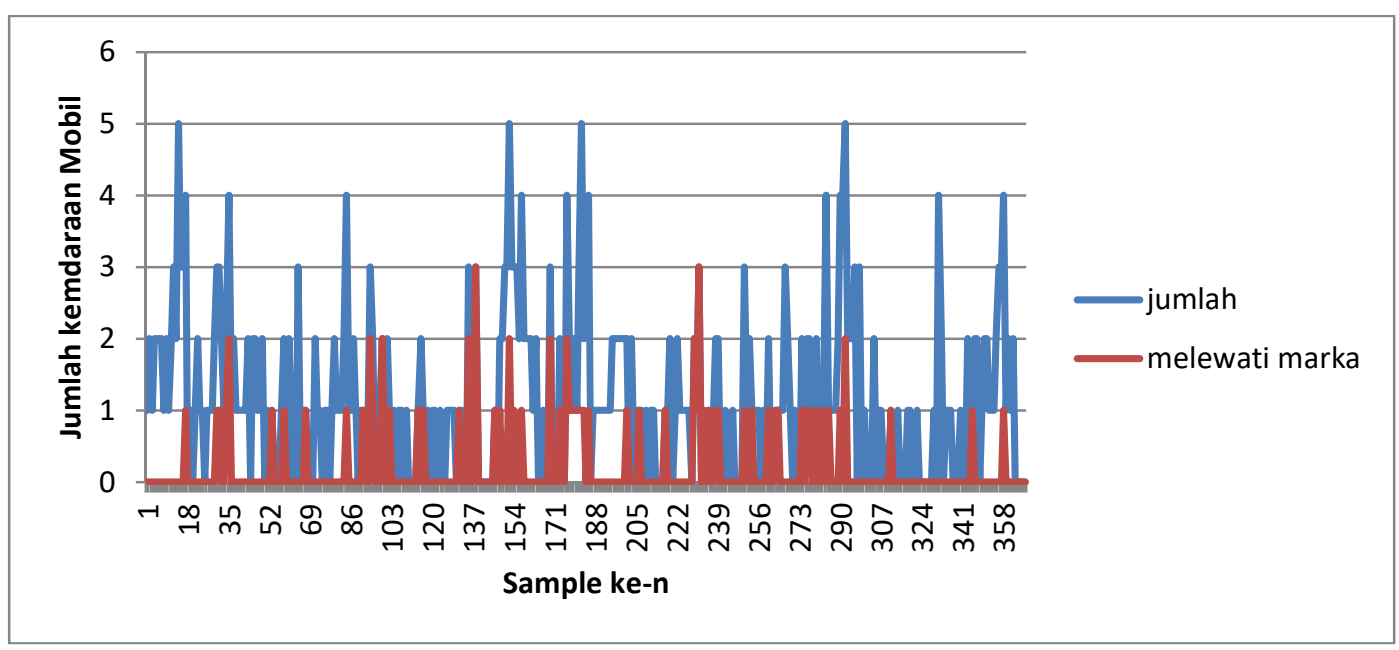

Gambar 7. Grafik jumlah kendaraan yang terdeteksi dan melanggar marka jalan

Gambar 7 menunjukkan jumlah kendaraan yang melewati area pemantauan dan dapat dideteksi oleh sistem, serta jumlah kendaraan mobil yang melanggar marka jalan ketika berhenti di area lampu lalu-lintas. Kurva warna biru menunjukkan jumlah mobil yang terdeteksi oleh sistem, sedangkan kurva warna merah menunjukkan jumlah kendaraan yang melanggar marka jalan dan dapat dideteksi oleh sistem. Sumbu vertikal menyatakan jumlah kendaraan yang terdeteksi oleh sistem, sedangkan sumbu horisontal adalah jumlah sampel pengamatan. Berdasarkan hasil output sistem dibandingkan dengan pengamatan langsung oleh mata manusia tingkat akurasi sistem dalam mendeteksi jumlah kendaraan yang melanggar marka jalan adalah sebesar $76 \%$.

\section{KESIMPULAN}

Berdasarkan rancangan, hasil uji sistem di lapangan beserta analisis pembahasannya, maka dapat disimpulkan bahwa sistem yang dikembangkan dapat melakukan pemantauan dan deteksi jumlah kendaraan yang melewati area pemantauan serta mendeteksi adanya pelanggaran marka jalan dengan akurasi deteksi sebesar $76 \%$. Nilai akurasi didapatkan dari hasil output sistem dibandingkan dengan pengamatan dan penilaian objektif mata manusia dari video yang diambil oleh kamera. Untuk pengembangan sistem lebih lanjut dari hasil penelitian yang telah dilakukan, sebaiknya menggunakan kamera dengan resolusi yang lebih tinggi dan penerapan algoritma lain yang lebih akurat.

\section{UCAPAN TERIMA KASIH}

Ucapan terima kasih disampaikan kepada semua pihak yang telah membantu, membimbing dan mengarahkan penelitian ini. Dengan segala bantuan yang telah penulis dapatkan maka penelitian ini dapat berjalan dan dapat terselesaikan dengan lancar. 


\section{DAFTAR RUJUKAN}

[1] M. Junef, "Perilaku Masyarakat Terhadap Operasi Bukti Pelanggaran (Tilang) Dalam Berlalu Lintas," E-J. Widya Yust., vol. 1, no. 1, 2014.

[2] D. Handayani, R. O. Ophelia, dan W. Hartono, "Pengaruh pelanggaran lalu lintas terhadap potensi kecelakaan pada remaja pengendara sepeda motor," Matriks Tek. Sipil, vol. 5, no. 3, 2017.

[3] A. M. Ali Mahdi Akbar, A. Kurniawan, dan A. Zaini, "Traffic IP Camera untuk Menghitung Kendaraan Roda Empat Menggunakan Metode Luasan Piksel," ITS.

[4] B. B. P. Utama, R. D. Atmaja, dan A. Azizah, "Analisa Algoritma Penghitung Kendaraan Roda Empat Dalam Kondisi Siang Dan Malam Hari Dengan Metode Frame Intersection," EProceedings Eng., vol. 4, no. 1, 2017.

[5] R. Adistya dan M. A. Muslim, "Deteksi dan Klasifikasi Kendaraan menggunakan Algoritma Backpropagation dan Sobel," hlm. 9, 2016.

[6] S. E. Umbaugh, Digital image processing and analysis: human and computer vision applications with CVIPtools. CRC press, 2010.

[7] S. Soo, "Object detection using Haar-cascade Classifier," Inst. Comput. Sci. Univ. Tartu, hlm. 1-12, 2014.

[8] C. Solomon dan T. Breckon, Fundamentals of Digital Image Processing: A practical approach with examples in Matlab. John Wiley \& Sons, 2011.

[9] R. D. Kusumanto dan A. N. Tompunu, "pengolahan citra digital untuk mendeteksi obyek menggunakan pengolahan warna model normalisasi RGB," Semantik, vol. 1, no. 1, 2011.

[10] B. Pribadi dan M. Naseer, "Sistem Klasifikasi Jenis Kendaraan Melalui Teknik Olah Citra Digital," Setrum Sist. Kendali-Tenaga-Elektron.-Telekomun.-Komput., vol. 3, no. 2, hlm. 103-107, 2016.

[11] R. Adistya dan M. A. Muslim, "Deteksi dan Klasifikasi Kendaraan menggunakan Algoritma Backpropagation dan Sobel," J. Mech. Eng. Mechatron., vol. 1, no. 02, 2016. 